\title{
DEFISIENSI COLLABORATIVE GOVERNANCE DALAM PENANGANAN PANDEMI COVID-19 DI INDONESIA
}

\author{
${ }^{1}$ Martina Purwaning Diah, ${ }^{2}$ Ike Arni Noventi, ${ }^{3}$ M. Rizki Pratama \\ 1,2,3 Fakultas IImu Administrasi Universitas Brawijaya \\ martina@ub.ac.id \\ Kota Malang, 65141, Indonesia
}

\begin{abstract}
The Covid-19 pandemic is a shared problem so it must also be resolved collectively. In the context of crisis, the role of the government must remain dominant, but also by opening the door to collaborative governance. Therefore it is vital to understand the dynamics of the collaborative governance process in dealing with the Covid-19 pandemic which of course is full of challenges and obstacles in the midst of uncertainty. Researchers use the literature study method to track various conditions in an effort to resolve a pandemic that involves inter-sectoral efforts, but researchers find important points that must be corrected so that the handling of the pandemic does not experience deficiencies in collaborative governance. So far, real action is needed in improving the responsiveness of policies, quality of regulations, data management, monitoring systems and coordination among sectors.
\end{abstract}

\section{Keywords: collaborative governance; covid-19; pandemic}

\begin{abstract}
Abstrak
Pandemi Covid-19 merupakan persoalan bersama sehingga juga harus diselesaikan secara bersama-sama pula. Dalam konteks krisis pun sebenarnya peran pemerintah harus tetap dominan akan tetapi juga dengan membuka pintu kolaborasi bersama dengan antar sektor (collaborative governance). Oleh karena itu penting untuk mengetahui dinamika proses collaborative governance dalam menangani pandemi Covid-19 yang tentu saja penuh dengan tantangan, kendala dan hambatan di tengah ketidakpastian. Peneliti menggunakan metode studi kepustakaan untuk melacak berbagai kondisi dalam usaha menyelesaikan pandemi yang melibatkan usaha antar sektor akan tetapi peneliti menemukan poin-poin penting yang harus diperbaiki agar penanganan pandemi tidak mengalami defisiensi dalam collaborative governance. Sejauh ini perlu tindakan nyata dalam memperbaiki responsivitas kebijakan, kualitas regulasi, manajemen data, sistem pengawasan dan koordinasi antar sektor.
\end{abstract}

Keywords: collaborative governance; covid-10; pandemi

Open Access at:http://ojs.uho.ac.id/index.php/PUBLICUHO/index

Journal Publicuho is licensed under a Creative Commons Attribution 4.0 International License. 


\section{PENDAHULUAN}

Penyebaran Corona Virus Disease 2019 (COVID-19) telah dinyatakan oleh Organisasi Kesehatan Dunia (World Health Organization) sebagai pandemi berskala global, di seluruh dunia termasuk Indonesia menunjukkan tren kasus positif dengan arah fatal yang pada akhirnya berimplikasi negatif pada aspek sosial, ekonomi, dan kesejahteraan masyarakat. Sebagai esensi Covid-19 yang telah dianggap sebagai masalah bersama maka pemerintah perlu berkolaborasi dengan antar sektor untuk dapat meningkatkan peluang sukses berbagai kebijakan dalam menanggulangi pandemi. Perlu hadirnya kerjasama kolaboratif (collaborative governance) untuk terjadi penyamaan visi, tujuan, strategi dan aktivitas antara para stakeholder tetapi memiliki otoritas untuk mengambil keputusan secara independen dan memiliki otoritas dalam mengelola organisasi walaupun mereka tunduk pada kesepakatan bersama (Dwiyanto, 2011). Sehingga pada akhirnya antar sektor dalam sebuah negara yang ingin menyelamatkan kesehatan dan ekonomi tidak berjalan dengan visinya sendiri-sendiri.

Ide dasarnya adalah bagaimana menciptakan pemerintahan yang baik dan benar sesuai prinsip dasar Good Governance. Hal ini sesuai dengan konsep goog governance yang secara sederhana Good Governance dapat diartikan sebagai kepemerintahan yang baik, selanjutnya World Bank mendefinisikannya sebagai suatu penyelenggaraan manajemen pembangunan yang solid dan bertanggung jawab yang sejalan dengan prinsip demokrasi dan pasar yang efisien, penghindaran salah alokasi dana investasi, dan pencegahan korupsi baik secara politik maupun administratif, menjalankan dispilin anggaran serta penciptaan legal and political framework bagi tumbuhnya aktivitas usaha Mardiasmo, 2002 dalam (Bakti, Ode, \& Elwan, 2018).

Berbagai kasus Institusi publik terutama Negara dan Pemerintahan Lokal yang memiliki kerangka governance terbukti dapat lebih memiliki daya tahan dalam menghadapi pandemi. Pemerintah Lokal Kerala di India mampu mendesain kolaborasi antar sektor untuk menciptakan Frugal Innovation di tengah keterbatasan sumber daya (Sarkar, 2020). Demikian juga dengan pemerintah Tiongkok yang sudah memiliki desain besar egovernance sehingga membantu dalam menanggulangi Covid-19 dengan bantuan kolaborasi antar sektor melalui teknologi informasi yang memadai (Ullah, et al. 2020).

Pada dasarnya collaborative governance dapat dilihat dari dua sudut pandang yaitu: pertama, dimensi proses kolaborasi yang memiliki titik tumpu pada siklus atau tahapan (Emerson, Nabatchi, \& Balogh, 2012; Ansell \& Gash, 2008; Thomson \& Perry, 2006, Emerson \& Murchie, 2010). Kedua, dimensi tindakan kolaborasi yang memiliki titik tumpu pada aksi kebijakan yang dilakukan oleh berbagai sektor dalam mencapai tujuan bersama secara kolaboratif (Agranoff \& McGuire, 2003; Emerson \& Murchie, 2010). Melalui dua sudut pandang tersebut maka collaborative governance dapat terlihat melalui berbagai macam 


\section{Journal Publicuho}

ISSN2621-1351 (online), ISSN 2685-0729 (print)

Volume 4 Number 2 (May-July), (2021)pp. 305-314

Accredited SINTA SK.NOMOR 28/E/KPT/2019

Open Access at:http://ojs.uho.ac.id/index.php/PUBLICUHO/index

DOI: 10.35817/jpu.v4i2.17619

aksi kebijakan yang dilakukan oleh berbagai sektor dalam tahapan tertentu seperti dalam konteks pandemi Covid-19 di Indonesia dengan membaca berbagai kebijakan yang muncul selama masa pandemi sementara kinerja penanganan pandemi di Indonesia adalah dalam tekanan karena penyebaran virus belum sepenuhnya dapat dikendalikan (Djalante, et al. 2020; Sparrow, et al. 2020).

Beberapa studi sebelumnya menunjukkan peran penting collaborative governance dalam berbagai sektor tata kelola pemerintahan di Indonesia seperti meningkatkan efektivitas dan efisiensi dan juga transparansi dan akuntabilitas (Furqoni, et al., 2019; Fauzi, et al., 2020; Rahmadanita, et al., 2018). Tentu berbagai riset tersebut masih dalam kondisi normal di mana pemerintah do as usual, akan tetapi terjadi perbedaan signifikan selama masa pandemi ini. Oleh karena itu penting untuk mengetahui dinamika proses collaborative governance dalam menangani pandemi Covid-19 yang tentu saja penuh dengan tantangan, kendala dan hambatan di tengah ketidakpastian yang belum pernah dihadapi sebelumnya sehingga dapat diketahui apa saja yang perlu diperbaiki untuk dapat menyelesaikan masalah pandemi Covid-19 sebagai masalah bersama.

\section{METODOLOGI}

Penelitian ini menggunakan pendekatan deskriptif dengan pendekatan studi kepustakaan. Studi kepustakaan adalah kegiatan untuk menghimpun informasi yang relevan dengan topik atau masalah yang menjadi obyek penelitian. Informasi tersebut dapat diperoleh dari bukubuku, karya ilmiah, ensiklopedia internet, dan sumber-sumber lain. Dengan melakukan studi kepustakaan, peneliti dapat memanfaatkan semua informasi dan pemikiran-pemikiran yang relevan dengan penelitiannya. Studi kepustakaan adalah teknik pengumpulan data dengan mengadakan studi penelaahan terhadap buku-buku, literatur-literatur, catatan-catatan dan laporan-laporan yang ada hubungannya dengan masalah yang dipecahkan (Nazir, 2013). Selanjutnya, studi kepustakaan merupakan langkah yang penting, dimana setelah seorang peneliti menetapkan topik penelitian, langkah selanjutnya adalah melakukan kajian yang berkaitan dengan teori topic penelitian. Dalam pencarian teori, peneliti akan mengumpulkan informasi sebanyak-banyaknya dari kepustakaan yang saling berhubungan (Nazir, 2013). Peneliti dalam studi ini menggunakan berbagai sumber-sumber kepustakaan baik digital ataupun versi cetak dari buku, jurnal, majalah, hasil-hasil penelitian, situs berita daring, aturan pemerintah dan lain sebagainya. Peneliti juga membatasi sumber data yang tersedia dan muncul selama tahun 2020. Pasca menemukan sumber yang relevan, maka peneliti segera menyusun secara teratur untuk dipergunakan dalam penelitian. Oleh karena itu studi kepustakaan yang peneliti lakukan adalah meliputi proses umum seperti mengidentifikasi teori secara sistematis, penemuan pustaka dan analisis dokumen yang 
memuat informasi yang berkaitan dengan collaborative governance dalam penanganan pandemi covid-19 di Indonesia.

\section{HASIL DAN PEMBAHASAN}

\section{Tumpang Tindih Regulasi}

Dalam konteks regulasi yang seharusnya memiliki daya dukung terhadap kolaborasi antar sektor ternyata dapat ditemukan berbagai masalah selama masa pandemi ini di Indonesia. Muncul berbagai peraturan yang saling berbenturan dengan peraturan setingkat lainnya sehingga menimbulkan kebingungan dalam menjalankannya seperti aturan Kebijakan Lockdown melalui Pembatasan Sosial Berskala Besar (PSBB). Tidak ada aturan konsisten dan tegas (Surya, 2020). Sehingga terjadi ketidakteraturan dalam menjalankan kebijakan tersebut karena berbagai daerah menetapkan aturan masing-masing sehingga dapat merugikan stakeholder lainnya. Dapat dilihat dalam permasalahan transportasi online ketika PSBB juga memiliki berbagai tumpang tindih aturan yang sering membingungkan pengguna dan provider. Seperti Kemenhub melalui Permenhub Nomor 18 yang mengizinkan ojol [ojek online] untuk mengangkut penumpang, akan tetapi dalam aturan Permenkes justru sebaliknya dengan pelarangan. Di sisi lain aturan operasi industri wisata juga berbeda-beda seperti Kementerian Perindustrian mengeluarkan aturan sendiri yang mengizinkan sejumlah industri beroperasi atas rekomendasi Kementerian. Padahal, dalam PP 21/2020, tertulis jelas hanya ada 8 sektor yang diizinkan beroperasi di masa PSBB (Media Indonesia, 20 April 2020).

\section{Lambatnya Respon Kebijakan}

Negara seharusnya hadir lebih awal dalam menyelesaikan masalah publik terutama dalam keadaan mendesak dan genting agar semua sektor dapat tetap memiliki trust satu sama lain dengan jaminan responsivitas negara dalam memberikan solusi. Akan tetapi dalam pandemi ini ternyata muncul berbagai delay dalam respon kebijakan yang membuat semua sektor untuk diam dan menunggu sehingga mengurangi respon kolaboratif untuk segera bergerak menyelesaikan masalah ketika pandemi merebak. Negara telah dikategorikan tidak tanggap atau memiliki daya tanggap rendah ketika menunjukkan kecenderungan meremehkan urgensi penanganan dan dampak pandemi di awal masa krisis (Mas'udi \& Winanti, 2020). Dapat terlihat dari lambatnya respon ketika temuan kasus positf pertama dengan terbatasnya tes yang dilakukan dan para pekerja medis yang kesulitan menemukan perlengkapan kesehatan untuk melindungi diri (Sasongkojati, 2020). Riset Agustino (2020) menunjukkan narasi negatif dan lambannya respon pemerintah atas penyebaran COVID-19. Dalam riset Dugis (2020) melihat juga pada masa awal pandemi merebak bahwa Sikap awal negara menentukan keberhasilan pengendalian COVID-19, Sikap awal yang dimaksud di sini adalah, ketika mendengar informasi awal tentang adanya penularan virus yang bermula dari Wuhan, China ini, apakah pemerintah langsung melihat itu sebagai wabah berpotensi mematikan (potentially deadly outbreak). Kesuksesan di 


\section{Journal Publicuho}

ISSN2621-1351 (online), ISSN 2685-0729 (print)

Volume 4 Number 2 (May-July), (2021)pp. 305-314

Accredited SINTA SK.NOMOR 28/E/KPT/2019

Open Access at:http://ojs.uho.ac.id/index.php/PUBLICUHO/index

DOI: 10.35817/jpu.v4i2.17619

Taiwan, Korea Selatan, Vietnam, Singapura, Australia, Selandia Baru, dan Jerman bermula dari keseriusan pemerintah ketika mendengar wabah COVID-19 sehingga dapat dengan cepat mengambil langkah responsif yang diperlukan sesuai dengan kondisi masing-masing negara (Dugis, 2020).

\section{Inkonsistensi Data}

Data merupakan elemen krusial dalam penanganan pandemi terutama untuk menjamin tersedianya informasi yang memadai guna pengambilan keputusan berbagai sektor sehingga tidak saling meragukan dan prosesnya dapat lebih cepat akan tetapi terjadi berbagai perbedaan data yang dimiliki oleh pemerintah. Perbedaan data antara pemerintah pusat, Ikatan Dokter Indonesa dan pemerintah daerah terkait dengan data penambahan pasien Covid-19 ini seringkali menimbulkan banyak kesulitan untuk merumuskan kebijakan yang tepat dikarenakan sumber data yang ada pun juga kurang tepat. Muncul juga data discrepancies (Syakriah, 2020), misalnya tercatat pada bulan Agustus tahun 2020 lalu: "There is a 318-figure gap between the reported fatalities and a 658-figure gap between the confirmed cases." Menurut Pambagio (2020) salah satu penyebabnya adalah kurang baiknya kinerja sistem teknologi informasi di pusat data dalam memasukkan data (data entry). Akibatnya data sering ter-entry berkali-kali atau bahkan tidak ter-entry sama sekali. Belum lagi masih banyak daerah yang belum memenuhi persyaratan jumlah contoh uji (sampel) per satu juta penduduk sesuai ketetapan WHO. Sehingga data yang terungkap belum merupakan data riil, kecuali data Pemprov DKI Jakarta yang relatif uji sampelnya sudah memenuhi standar WHO.

\section{Lemahnya Pengawasan}

Dalam situasi krisis tentu pengawasan pemerintah kepada seluruh sektor adalah penting di mana seharusnya sistem pengawasan yang berjalan dapat membuat seluruh sektor menaruh kepercayaan sehingga meningkatkan intensitas kolaborasi akan tetapi terjadi berbagai kelemahan mendasar. Kurangnya pengawasan yang dilakukan oleh pemerintah sehingga muncul kontroversi klaim rumah sakit terhadap pasien non Covid-19 untuk dilaporkan sebagai pasien Covid-19 agar Rumah Sakit mendapat bantuan dana perawatan (Republika, 21 Oktober 2020; Kompas, 5 Oktober 2020; Fajar, 3 Oktober 2020). Dalam konteks pengawasan ketika pandemi ini Indonesia dapat tergolong lemah dengan terlihat dari pengawasan kesehatan seperti screening dan surveilance untuk melacak mobilitas masyarakat dan juga pengawasan kebijakan seperti penyaluran berbagai bantuan sosial kepada masyarakat yang terdampak pandemi. Pengawasan kesehatan ternyata penuh dengan lubang. Dewan Pakar Ikatan Ahli Kesehatan Masyarakat Indonesia dan Persatuan RS Seluruh Indonesia, Hermawan Saputra menilai Indonesia masih lemah dalam pengawasan virus Corona atau COVID-19. "Di pintu-pintu masuk kita, baik di embargo, 
penerbangan, kita itu sebenarnya masih lemah. Kita masih banyak hanya mengandalkan thermal scanner" (Tirto.id, 29 Januari 2020). Selain itu dugaan kasus korupsi Bansos Kemensos telah menunjukkan lemahnya pengawasan penyaluran bantuan sosial selama pandemi ini (Kompas, 6 Desember 2020).

\section{Kurangnya Koordinasi}

Dalam kolaborasi antar sektor koordinasi dalah kunci untuk memastikan tercapainya tujuan bersama akan tetapi dalam implementasinya sendiri dari sisi pemerintah ternyata tidak demikian. Kurangnya koordinasi antar bidang satu dengan bidang lainnya. Kebijakan publik yang bersifat cepat perlu diambil pemerintah dalam masa darurat penyebaran Covid-19. Selain itu, juga dibutuhkan adanya transparansi data serta kebijakan agar membuat masyarakat dapat memberikan kepercayaan kepada masyarakat. kebijakan yang dikeluarkan juga harus komprehensif dan independen. Disamping hal tersebut, komunikasi dan stimulus yang efeketif untuk dapat membentuk kepercayaan publik pada pemerintah .Pemerintah masih kurang dalam menyebarluaskan kebijakan yang ada guna menekan penyebaran Covid-19. Bagaimana kebijakan pemerintah, prosedur kesehatan untuk memutus mata rantai Covid-19 agar masyarakat berlaku sesuai anjuran, dan hukuman apa yang akan didapat bagi pelanggar aturan juga masih belum jelas. Ketidaksingkronan koordinasi antara pemerintah pusat dan pemerintah daerah mengakibatkan pengendalian virus korona menjadi terkatung-katung (Agustino, 2020). Berbagai sektor juga telah melakukan kritik terhadap kurangnya koordinasi pemerintah sendiri, seperti Dewan Perwakila Rakyat (DPR) yang mengkritik tajam koordinasi pemerintah pusat dengan pemerintah daerah (Kompas, 2 September 2020). Selain itu Pengurus Besar Nahdatul Ulama juga mengkritik hal yang sama terkait koordinasi pemerintah pusat dengan pemerintah daerah yang masih belum optimal (CNN Indonesia, 29 Desember 2020).

\section{Dinamika Proses Collaborative Governance di Indonesia: Defisiensi}

Analisis data menunjukkan berbagai kelemahan berarti dalam penanganan pandemi Covid-19 di Indonesia berdasarkan kacamata proses Collaborative Governance (Tabel 1.). Berbagai aksi kebijakan dalam berbagai tahapan selama pandemi Covid-19 menunjukkan arah yang kurang menggembirakan. Berbagai dimensi menunjukkan bahwa Collaborative Governance dalam penanganan pandemi di Indonesia cenderung terhambat dari sisi internal pemerintah sendiri sehingga mengalami defisiensi atau "kurang gizi". Dimensi regulasi yang disediakan oleh pemerintah mengalami tumpang tindih, respon kebijakan pemerintah juga cenderung lambat, data yang disediakan juga dianggap inkonsisten oleh berbagai pihak, ditambah pengawasan kebijakan internal pemerintah selama masa pandemi yang lemah, dan bahkan koordinasi antar sektor pemerintah sendiri juga kurang dan terfragmentasi oleh ego sektoral. 


\section{Journal Publicuho}

ISSN2621-1351 (online), ISSN 2685-0729 (print)

Volume 4 Number 2 (May-July), (2021)pp. 305-314

Accredited SINTA SK.NOMOR 28/E/KPT/2019

Open Access at:http://ojs.uho.ac.id/index.php/PUBLICUHO/index DOI: 10.35817/jpu.v4i2.17619

Pada dasarnya faktor yang mempengaruhi collaborative governance terdiri dari tiga dimensi yaitu pertama, dimensi struktural dan institusional, kedua, dimensi stakeholder dan ketiga dimensi relasi diantara stakeholders (Tantrajin, 2020). Faktor lain juga dapat dimunculkan seperti faktor struktur sosial, kultural dan kepentingan pemerintah (Sepriandi \& Hussein, 2019). Secara lebih praktikal Ansell \& Gash (2007)memberikan saran bahwa agar Collaborative Governance dapat bekerja dengan baik harus menggunakan dialog, pembangunan kepercayaan dan pengembangan komitmen dan pemahaman bersama. Faktor-faktor tersebut dapat terbagi menjadi dua bagian besar yaitu faktor internal dan eksternal jika pusat inisiasi pada pemerintah terutama dalam kondisi krisis seperti pandemi Covid-19. Melihat pada sudut pandang tersebut maka dapat dipastikan jika kegagalan fungsi internal pemerintah dalam menyediakan regulasi, respon kebijakan, data, pengawasan, serta koordinasi yang memadai telah menghambat proses collaborative governance antar sektor lainnya terutama mengakibatkan kegagalan pembangunan kepercayaan dan pembangunan komitmen serta pemahaman bersama. Di sisi lain dalam pengembangan teori collaborative governance juga belum dikaitkan dengan inklusivitas kebijakan selama pandemi ini terkait dengan pelibatan kelompok miskin, adat dan marjinal yang sering terlupakan dalam agenda (Ansell, et al. 2020).

Tabel 1. Rangkuman Analisis Data

\begin{tabular}{lll}
\hline No & Dimensi & Temuan \\
\hline 1. & Regulasi & Tumpang Tindih \\
\hline 2. & Respon Kebijakan & Lambat \\
\hline 3. & Data & Inkonsisten \\
\hline 4. & Pengawasan & Lemah \\
\hline 5. & Koordinasi & Kurang \\
\hline
\end{tabular}

Sumber: analisis data, 2020

\section{KESIMPULAN}

Dinamika proses collaborative governance dalam penanganan pandemi di Indonesia mengalami defisiensi karena berbagai hambatan dalam masing-masing elemen yang sudah dilakukan dari sisi pemerintah sendiri sehingga memicu keengganan, kurangnya kepercayaan dan lambatnya sektor-sektor lain untuk segera menata diri untuk berkolaborasi menyelesaikan masalah-masalah yang muncul dalam masa pandemi selama ini. Pada awal masa pandemi respon kebijakan pemerintah dapat dikatakan lambat dalam merespon awal masuknya Covid-19 di Indonesia. Selama itu pula muncul berbagai regulasi yang juga tumpang tindih sehingga membingungkan berbagai sektor terutama ketika implementasi PSBB. Berbagai data yang disediakan pemerintah juga menunjukkan inkonsistensi dalam perbedaan data antar sektor yang masih ditambah dengan masalah uji sampel yang belum 
dapat memenuhi standar. Selain itu pengawasan pemerintah pada masa pandemi ini juga lemah dengan kurang optimalnya screening, surveillence dan tracing diperparah dengan dugaan kasus korupsi bantuan sosial. Munculnya ego sektoral antar Kementerian, Pemerintah pusat dan Pemerintah daerah juga menunjukkan kurang koordinasi antar insititusi dalam menyelesaikan masalah bersama. Oleh karena itu memahami masalah pandemi sebagai masalah publik tentu menegaskan bahwa persoalan tersebut tidak akan selesai tanpa adanya kolaborasi antar sektor, akan tetapi sejauh ini perlu tindakan koreksi nyata dalam memperbaiki responsivitas kebijakan, kualitas regulasi, manajemen data, sistem pengawasan dan koordinasi antar sektor untuk segera lepas dari jeratan pandemi Covid-19.

\section{REFERENSI}

Agranoff, Robert \& Michael McGuire. (2003). Collaborative public management. Washington, DC: Georgetown Univ.

Agus Dwiyanto. (2011). Mengembalikan Kepercayaan Publik Melalui Reformasi Birokrasi. PT Gramedia Pustaka Utama: Jakarta.

Agustino, Leo. (2020). Analisis Kebijakan Penanganan Wabah Covid-19: Pengalaman Indonesia. Jurnal Borneo Administrator. 16 (2).

Annisa Rahmadanita, Eko Budi Santoso, dan Sadu Wasistiono. (2018). Implementasi Kebijakan Smart Government Dalam Rangka Mewujudkan Smart City Di Kota Bandung. Jurnal IImu Pemerintahan Widya Praja. Vol. 44, No. 2, Oktober 2018:81- 106

Ansell, Chris, \& Alison Gash, (2007). Collaborative Governance in Theory and Practice. Journal of Public Administration Research and Theory. Vol.18 No.4, HIm. 543-571

Ansell, Christopher, Carey Doberstein, Hayley Henderson, Saba Siddiki \& Paul 't Hart (2020) Understanding inclusion in collaborative governance: a mixed methods approach. Policy and Society. 39:4, 570-591, DOI: 10.1080/14494035.2020.1785726.

Bakti, O.: Ode, L., \& Elwan, M. (2018). ANALISIS RESTRUKTURISASI BIROKRASI DALAM PENGEMBANGAN GOOD GOVERNANCE PADA SEKERTARIAT DAERAH KABUPATEN KONAWE UTARA. 1 (3), 1-13. Retrieved from http://ojs.uho.ac.id/index.php/PUBLICUHO

CNN Indonesia. (2020). PBNU Kritik Penanganan Covid: Koordinasi Lemah. https://www.cnnindonesia.com/nasional/20201229195412-20-587581/pbnu-kritikpenanganan-covid-koordinasi-lemah

Dugis, Vinsensio. (2020). State Response to the COVID-19 Pandemic. Global Strategis. 14 (2).

Emerson, Kirk, and Peter Murchie. (2010). Collaborative governance and climate change: Opportunities for public administration. In The future of public administration, public management, and public service around the world: The Minnowbrook perspective, eds. R. O'Leary, D. Van Slyke, and S. Kim, 141-53. Washington, DC: Georgetown Univ.

Emerson, Kirk., Tina Nabatchi \& Stephen Balogh. (2012). Integrative Framework for Collaborative Governance. Journal of Administration Research and Theory. Vol. 22 no. 1. hal. 1-29. 


\section{Journal Publicuho}

ISSN2621-1351 (online), ISSN 2685-0729 (print)

Volume 4 Number 2 (May-July), (2021)pp. 305-314

Accredited SINTA SK.NOMOR 28/E/KPT/2019

Open Access at:http://ojs.uho.ac.id/index.php/PUBLICUHO/index

DOI: 10.35817/jpu.v4i2.17619

Erinda Alfiani Fauzi, Achmad Nurmandi \& Ulung Pribadi. (2020). A Literature Review on Smart City and Smart Governance. JPPUMA: Jurnal IImu Pemerintahan dan Sosial Politik UMA (Journal of Governance and Political Social UMA), 8(1).

Fajar. (2020). Kasus Mencovidkan Marak IPW Polri Harus Bongkar Mafia Rumah Sakit. https://fajar.co.id/2020/10/03/kasus-mencovidkan-marak-ipw-polri-harus-bongkarmafia-rumah-sakit/

Iqtikaful Furqoni, Slamet Rosyadi,dan Alizar Isna. (2019). Collaborative Governance in Corporate Social Responsibility Forum in Banyumas Regency. Jurnal Bina Praja 11 (2) (2019): 209-217

Kompas. (2020). 6 Bulan Covid-19, Anggota DPR Kritik Koordinasi Pusat-Daerah dan Anggaran yang Fokus di Perekonomian. https://nasional.kompas.com/read/2020/09/02/12194691/6-bulan-covid-19anggota-dpr-kritik-koordinasi-pusat-daerah-dan-anggaran?page=all.

Kompas. (2020). Korupsi Bansos Covid-19: Mensos Juliari Diduga Terima Rp 17 Miliar hingga Bukti Uang dalam Koper. https://nasional.kompas.com/read/2020/12/06/09194161/korupsi-bansos-covid-19mensos-juliari-diduga-terima-rp-17-miliar-hingga?page=all.

Kompas. (2020). Saat Rumah Sakit Dituding Meng-covid-kan Pasien. https://nasional.kompas.com/read/2020/10/05/15350241/saat-rumah-sakit-ditudingmeng-covid-kan-pasien?page=all

Mas'Udi, Wawan \& Poppy S. Winanti (ed). (2020). Tata Kelola Penanganan COVID-19 di Indonesia: Kajian Awal. Gadjah Mada University Press: Yogyakarta.

Media Indonesia. (2020). Regulasi Tumpang Tindih dan Bertentangan Persulit Penegakan Hukum. https://mediaindonesia.com/politik-dan-hukum/305730/regulasi-tumpangtindih-dan-bertentangan-persulit-penegakan-hukum

Nazir, Moh. (2013). Metode Penelitian. Ghalia Indonesia: Bogor.

Pambagio, Agus. (2020). Akurasi Kelola Data Pandemi Covid-19. https://kumparan.com/agus-pambagio/akurasi-kelola-data-pandemi-covid-19lU1MPTO8QCH/fUll

Pambagio, Agus. (2020). Inkonsistensi Kebijakan Indonesia. https://kumparan.com/aguspambagio/inkonsistensi-kebijakan-indonesia-1 voalZVwpTm/full

Republika. (2020). Menteri Terawan Komentari Tudingan RS Mengcovidkan Pasien. https://republika.co.id/berita/aiihya354/menteri-terawan-komentari-tudingan-rsmengcovidkan-pasien

Riyanti Djalante, Jonatan Lassa, Davin Setiamarga, Aruminingsih Sudjatma, Mochamad Indrawan, Budi Haryanto, Choirul Mahfud, Muhammad Sabaruddin Sinapoy, Susanti Djalante, Irina Rafliana, Lalu Adi Gunawan, Gusti Ayu Ketut Surtiari, Henny Warsilah. (2020). Review and analysis of current responses to COVID-19 in Indonesia: Period of January to March 2020, Progress in Disaster Science, Volume 6. https://doi.org/10.1016/j.pdisas.2020.100091.

Sarkar S. (2021). Breaking the chain: Governmental frugal innovation in Kerala to combat the COVID-19 pandemic. Government information quarterly. 38(1), 101549. https://doi.org/10.1016/i.gia.2020.101549

Sasongkojati, R Moh Hiu Dilangit Ramadhan. (2020). Covid-19: Indonesia Needs to Consider Pandemic Diseases a National Security Issues. CSIS Commentaries DMRU-061-EN. 
Sepriandi, Sigit \& Rahmawati Hussein. (2019). Faktor-Faktor yang Mempengaruhi Collaborative Governance dalam Penanganan Pekerja Migran Bermasalah di Kota Tanjungpinang. Jurnal IImu Pemerintahan dan Sosial Politik UMA. 7 (1).

Sparrow, Robert, Teguh Dartanto \& Renate Hartwig (2020) Indonesia Under the New Normal: Challenges and the Way Ahead, Bulletin of Indonesian Economic Studies, 56:3, 269299, DOI: 10.1080/00074918.2020.1854079.

Surya, T. Ade. (2020). Inkonsistensi dan Ketidaktegasan Kebijakan Pemerintah dalam Menangani Pandemi COVID-19. Info Singkat Pusat Penelitian Badan Keahlian DPR RI. XII (8).

Syakriah, Ardilla. (2020). Data Discrepancies Persist Five Months into Pandemic. https://www.thejakartapost.com/news/2020/08/1 1/data-discrepancies-persist-fivemonths-into-pandemic.html

Tantrajin, Patcharapa. (2020). Collaborative Governance: Factors Affecting its Formation and Implementations. Burapha Journal of Political Economy. 8 (1).

Thomson, Ann Marie., and James Perry. (2006). Collaboration processes: Inside the black box. Public Administration Review. 66:20-32.

Tirto.id. (2020). Pengawasan Indonesia Atas Corona atau COVID-19 Dinilai Masih Lemah. https://tirto.id/pengawasan-indonesia-atas-corona-atau-covid-19-dinilai-masihlemah-eB 11

Ullah, A., Pinglu, C., Ullah, S., Abbas, H., \& Khan, S. (2020). The Role of E-Governance in Combating COVID-19 and Promoting Sustainable Development: A Comparative Study of China and Pakistan. Chinese Political Science Review, 1-33. Advance online publication. https://doi.org/10.1007/s41111-020-00167-w 